\title{
The invasive crayfish Cherax quadricarinatus facing chlordecone in Martinique: Bioaccumulation and depuration study
}

\author{
Thomas Baudry ${ }^{\mathrm{a}, \mathrm{b}, \mathrm{c}, \mathrm{d},{ }^{*}, \text { Eric Gismondi }}{ }^{\mathrm{e}}$, Jean-Pierre Goût ${ }^{\mathrm{a}}$, Alexandre Arqué ${ }^{\mathrm{b}}$, \\ Juliette Smith-Ravin ${ }^{\mathrm{d}}$, Frédéric Grandjean ${ }^{\mathrm{c}}$ \\ a DEAL Direction de l'Environnement, de l'Aménagement et du Logement, Route de la Pointe de Jaham, BP7212, Schoelcher, 97274, Martinique \\ ${ }^{\mathrm{b}}$ ODE Office De l'Eau, 7 Avenue Condorcet, Fort-de-France, Martinique \\ ${ }^{\mathrm{c}}$ Laboratoire Ecologie et Biologie des Interactions, UMR CNRS 7267 Equipe Ecologie Evolution Symbiose, 5 Rue Albert Turpin, Poitiers Cedex, France \\ ${ }^{\mathrm{d}}$ Groupe de Recherche BIOSPHERES, Universite des Antilles, Campus de Schoelcher, F.W.I, Martinique \\ ${ }^{\mathrm{e}}$ University of Liège, Laboratory of Animal Ecology and Ecotoxicology (LEAE) - Freshwater and OceaniC Sciences Unit of ReSearch (FOCUS), Chemistry Institute, Bât. \\ B6C, 11 Allée du 6 Août, B-4000, Sart-Tilman, Belgium
}

\section{H I G H L I G H T S}

- CLD contamination of Cherax quadricarinatus wild population.

- Toxicokinetics of CLD in C. quadricarinatus in laboratory conditions.

- Positive correlation between CLD concentrations in water and crayfish muscle.

- 20-day decontamination ineffective to achieve MRL in crayfish muscle exposed to $2 \mu \mathrm{g} / \mathrm{L}$.

- Human health concern for Martinican consumers.

\section{A R T I C L E I N F O}

Handling Editor: Alvine C.Mehinto

\section{Keywords:}

Aquatic ecotoxicology

Decapoda

French West Indies

Invasive species

POP

\begin{abstract}
A B S T R A C T
The redclaw crayfish, Cherax quadricarinatus, was introduced to Martinique Island for aquaculture purposes at the beginning of the 21st century, in an attempt to revitalize the freshwater crustacean aquaculture sector. Mainly due to its high economical value, it was intentionally released in the wild and was caught and sold by fishermen. Martinican rivers are polluted by chlordecone, considered as one of the worst Persistant Organic Pollutants (POP). Despite its dangerousness, it was used until 1993 in the French West Indies against a banana pest and was always found in the ecosystems. This study aimed to investigate the level of contamination in the muscle of crayfish caught in the wild, as well as the potential of bioconcentration and depuration in the C. quadricarinatus muscle. This study could allow us to quantify the risk for consumers but also, to evaluate a depuration process to reduce the risk related to its consumption. Using both in-vitro and in-situ experiments, results highlighted the importance of the chlordecone concentration in the water and the time of exposure to the pollutant. The bioconcentration seems to be very quick and continuous in crayfish muscle, as chlordecone can be detectable as early as $6 \mathrm{~h}$ of exposure, whatever the concentration tested. Finally, it appears that, even after 20 days of depuration in chlordecone-free water, chlordecone concentrations remained higher to the residual maximum limit (i.e. $20 \mathrm{ng} / \mathrm{g}$ wet weight), concluding that the decontamination of the muscle seems not very efficient, and the risk for the Martinican people could be serious.
\end{abstract}

\section{Introduction}

Worldwide aquaculture development is known to be a pathway for the introduction of non-native species to new countries (FAO, 2016). It can lead to the transfer of organisms into new ecosystems facilitated by humans especially when sold alive and at a high price. It can result in

\footnotetext{
* Corresponding author. DEAL Direction de l'Environnement, de l'Aménagement et du Logement, Route de la Pointe de Jaham, BP7212, Schoelcher, 97274, Martinique

E-mail address: thmsbaudry@gmail.com (T. Baudry).
} 
serious aquatic invasions threatening native aquatic ecosystems (Filipová et al., 2013).

The Australian redclaw crayfish Cherax quadricarinatus, is a good example as it was translocated to many territories in tropical and subtropical areas (references in Baudry et al., 2020) for aquaculture, due to its high reproductive capacity and rapid growth (Jones, 1990; Patoka et al., 2014; Azofeifa-Solano et al., 2017). In Martinique, a tense ecological situation led to the closure of many aquaculture facilities raising the shrimps Macrobrachium rosenbergii. In fact, most of the soils where this species was produced became contaminated with chlordecone (CLD). Only one farm was able to survive by exporting its activity to a smaller site, making the production of $M$. rosenbergii unprofitable and forcing the farmer to find an alternative (Baudry et al., 2020). Cherax quadricarinatus was finally introduced to the island in the early 2000s, from Cuba, in order to reinvigorate this sector (Baudry et al., 2020). Following intentional releases, crayfish were found in the natural environment and, thanks to their high dispersal capacity and its high tolerance of environmental quality, were able to colonize a large part of the island's river systems (Baudry et al., 2021).

In the international toxicological context, several studies have shown that invasive species have a higher absorption potential than native ones, particularly in the presence of abiotic stressors (Fedorenkova et al., 2013; Pedro et al., 2017). For example, Pedro et al. (2017) show a higher concentration of POPs in non-native fish species capelin and sandlance (Mallotus villotus and Ammodytes spp.) than in the native Arctic cod (Boreogadus saida). Weir and Salice (2012) show the higher resistance of the snail species Melanoides tuberculatus to malathion compared to the native Biomphalaria glabrata. In bryozoans, large drops in biomass, often with no recovery, are observed in native species exposed to heavy metals, whereas in non-native species, an increase in biomass is sometimes even observed (Crooks et al., 2011).

French West Indies soils and rivers are contaminated by chlordecone (CLD) $\left(\mathrm{C}_{10} \mathrm{Cl}_{10} \mathrm{O}\right.$; CAS number 143-50-0) (Coat et al., 2006; Lafontaine et al., 2017b), considered to be the worst Persistent Organic Pollutant (POP) for these areas. It was widely used to eliminate the banana weevil (Cosmopolites sordidus), considered the most important banana crop pest (Serge, 1994; Cabidoche and Lesueur-Jannoyer, 2012). The hazards of this pollutant are known and led to a refusal to register it by the Toxics Commission and the ban of its use in 1977 by the United States (Cannon et al., 1978). Indeed, chlordecone is well known to be an endocrine disruptor and could also be responsible for other diseases such as prostate cancer, for example (Multigner et al., 2007, 2010). In France, CLD was only prohibited in 1990 and the French West Indies obtained a 3-year derogation, until 1993, waiting to find an alternative to this pesticide (Cabidoche et al., 2009; Cabidoche and Lesueur-Jannoyer, 2012).

Like most pesticides, CLD can be bioaccumulated along trophic chains (Bahner et al., 1977; Hansen et al., 1977). This is rather worrying given that aquatic ecosystems are well known to be the final receptacle of these toxic molecules through soil leaching and/or erosion processes (Snegaroff, 1977; Coat et al., 2006; Cabidoche and Lesueur-Jannoyer, 2012). Because of its very high persistence in soils, CLD is still present

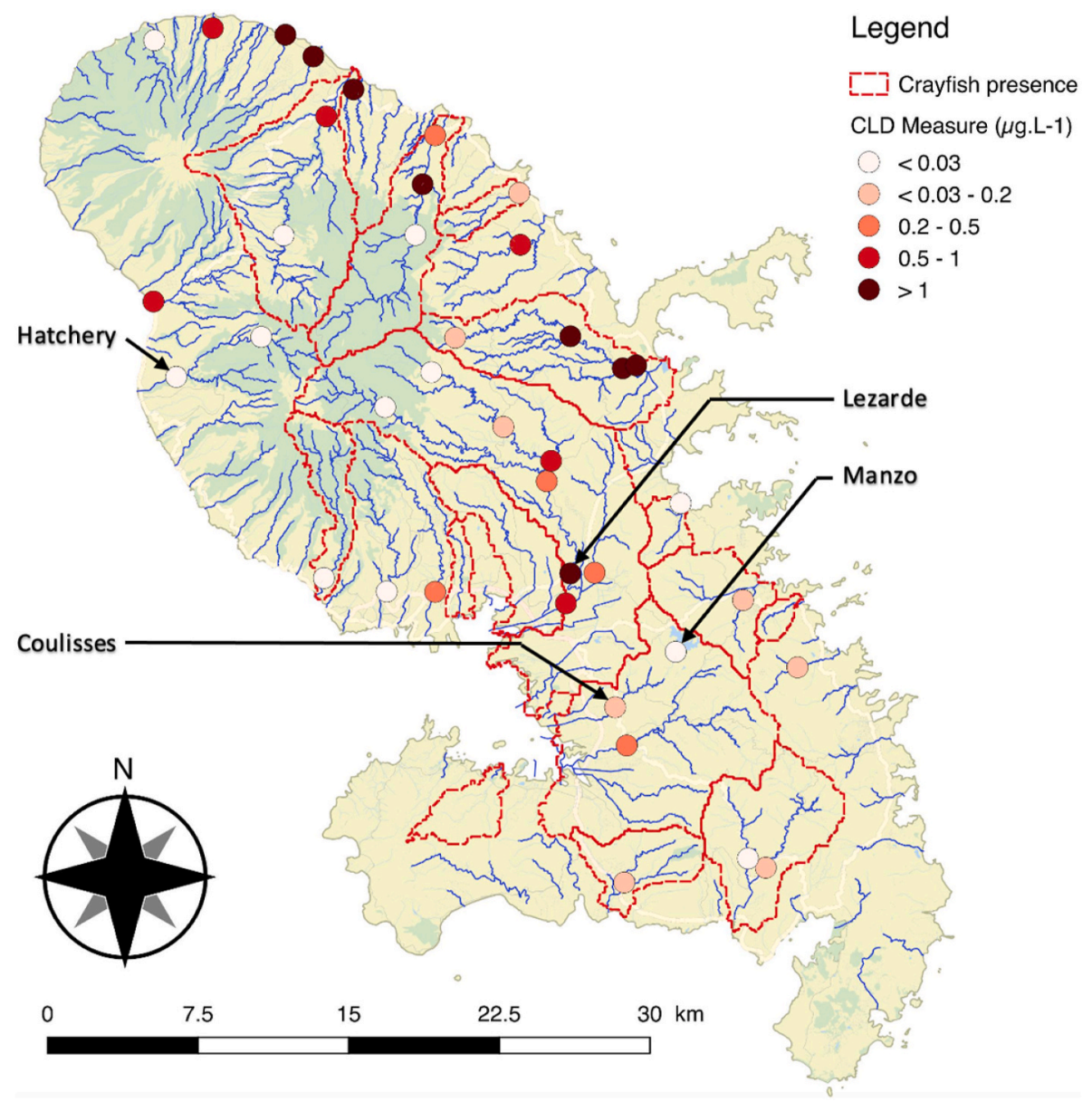

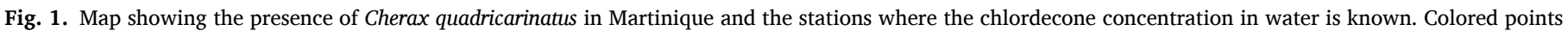

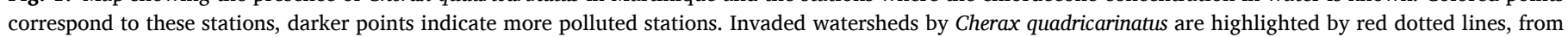
data in Baudry et al. (2021). (For interpretation of the references to colour in this figure legend, the reader is referred to the Web version of this article.) 
today in soils and rivers of Martinique (Merlin et al., 2016) and also in biota. Indeed, several studies highlighted a positive correlation between CLD concentrations in the water and CLD concentrations measured in organisms (Hansen et al., 1977) with potentially very high bioconcentration factors (Bahner et al., 1977). This highlights the dangerousness of the situation in Martinique given that C. quadricarinatus, having a preference for slow-moving waters, often located downstream and therefore receiving a large dose of pollutants, is highly likely to accumulate substantial doses of CLD. Highly appreciated by local fishermen, $C$. quadricarinatus is fished in the wild and resold at high prices on the markets or to restaurants, but this could raise a major human health problem in the population, given the high doses of chlordecone found in the water at some sites, especially in the North of Martinique (Fig. 1). CLD concentrations in Martinican rivers can be very variable (Fig. 1). Fig. 1 exposed the variability in terms of CLD concentration in the water. This variability can be explained, for example, by different CLD amount used in the past by each banana plantation owner, known to be largely located in the North. This observation could also by due to the type of soil which plays a role in the CLD retention and depending on the location of the different plantations, from north to south, the soil composition is not the same. Indeed, Cabidoche et al. (2009) modeled the persistence of chlordecone in different type of soil and highlighted that CLD is more persistent in andosol than nitisol. Finally, CLD concentrations measured in rivers are also dependent to the rainfall, responsible for soil leaching, and the North of the island is known to be more exposed to the rainfalls. As the problem is destined to persist over time, given that CLD has a very long persistence in the environment, the French health authorities have set a Maximum Residual Limit (MRL), above which products are considered consumable, which is at $20 \mathrm{ng} \mathrm{g}^{-1}$ wet weight.

Therefore, the aims of this study were to (i) investigate the presence of CLD in the abdominal muscle (part consumed by humans) of C. quadricarinatus collected from three Martinican rivers according to a contamination gradient (biomonitoring), then (ii) determine the kinetics of bioconcentration of CLD in C. quadricarinatus muscle under controlled laboratory conditions to understand the bioconcentration mechanism and finally, (iii) investigate a potential decontamination of the crayfish before its consumption, to assess its risk as a food product.

\section{Material and method}

\subsection{Is CLD bioaccumulated in wild crayfish?}

Three sites, known to be contaminated by chlordecone, and a control site (uncontaminated) were selected to investigate the potential of C. quadricarinatus to accumulate CLD.

The four sites were selected according to a CLD-gradient of contamination, representing the main CLD concentrations measured in Martinique rivers where crayfish populations were observed (Baudry et al., 2021). These four sites were: a non-contaminated site, corresponding to the hatchery (CLD concentration in the water $<$ limit of detection (LOD)), a low contaminated site "Manzo" (below quantification limit $0.03 \mu \mathrm{g} . \mathrm{L}^{-1}$ ), an intermediate station on the Coulisses stream (annual mean $0.45 \mu \mathrm{g} . \mathrm{L}^{-1}$ ) and a highly contaminated station, on the Lezarde river (annual mean $2.48 \mu \mathrm{g} . \mathrm{L}^{-1}$ ). At each sampling site, five male crayfish were collected, between 10 and $14 \mathrm{~cm}$ (i.e. adult stage), weighed and measured. Only males were analyzed to avoid possible bias in analysis due to the reproductive cycle in females (Lafontaine et al., 2017b). After sampling, abdominal muscle was dissected in laboratory, weighed and stored at $-20{ }^{\circ} \mathrm{C}$ until analysis.

\subsection{What are the CLD bioconcentration and depuration kinetics in crayfish in laboratory conditions?}

\subsubsection{Kinetics of bioconcentration}

A total of 180 crayfish males were provided by a hatchery in Carbet
(Martinique), a CLD-free area, according to results of 'Office de l'Eau de Martinique' (ODE). They were all between 10 and $14 \mathrm{~cm}$ body length and between 15 and $59 \mathrm{~g}$ (the most common size range in the Martinique rivers, Personal observation) and were transferred to the laboratory of IFREMER, Le Robert, Martinique. As for in-situ experiments, only males were used, to avoid bias due to reproduction cycle in females.

Thirty $20 \mathrm{~L}$ aquaria were filled with CLD-free water. Crayfishes were acclimated, for seven days before experiments, under constant oxygenation aeration and a natural light/dark photoperiod. Water temperature and $\mathrm{pH}$ were maintained at $27^{\circ} \mathrm{C} \pm 0.11$ and $7.72 \pm 0.28$ corresponding to optimal values for C. quadricarinatus development (de Moor, 2002; Tropea et al., 2010). Crayfish were fed daily with pieces of carrot.

Exposure was carried out using two chlordecone conditions: $0.2 \mu \mathrm{g}$. $\mathrm{L}^{-1}, 2 \mu \mathrm{g} . \mathrm{L}^{-1}$, chosen for their environmental relevance in rivers of Martinique, and a control (containing $0.01 \%$ acetone, corresponding to the use of prepared stock solutions of CLD in acetone). Intermediate solutions were prepared with two successive dilutions from CLD (GC purity area $\geq 98 \%$; Sigma-Aldrich, USA): first, a 1 g.L - $^{-1}$ CLD stock solution was prepared with $100 \%$ acetone and then, a $10 \mathrm{mg} . \mathrm{L}^{-1}$ CLD solution was prepared with water (therefore containing $1 \%$ acetone), used in exposure media preparation. The real CLD concentrations of exposure were measured at the Laboratoire Territorial d'Analyze (LTA) of Martinique (Table 1).

Ten aquaria per condition were used (six individuals per aquarium). As for the acclimation period, crayfishes were fed daily with pieces of carrot, small enough (around $0.125 \mathrm{~cm}^{3}$ ) to be eaten quickly and avoid a possible adsorption of pollutant. According to Lafontaine et al. (2017b), to keep a constant CLD concentration in water during all the experiments, it is necessary to perform a 7-day period to saturate the aquariums' walls before exposure, and renew the exposure medium every 96 h.

To analyze the CLD concentration in C. quadricarinatus, five individuals per condition were randomly sampled in aquariums after six exposure times: $6 \mathrm{~h}, 1 \mathrm{day}, 2 \mathrm{~d}, 6 \mathrm{~d}, 12 \mathrm{~d}$ and $20 \mathrm{~d}$. The abdominal muscle was dissected, weighed and conserved at $-20{ }^{\circ} \mathrm{C}$ until analysis.

\subsubsection{Kinetics of depuration}

At the end of the bioconcentration experiment (i.e. 20 days), the remaining individuals (from 0.2 to $2 \mu \mathrm{g} . \mathrm{L}^{-1}$ exposure) were rinsed thoroughly with CLD-free water (to avoid possible traces of CLD adsorbed on the cuticle) and transferred to different aquaria filled with CLD-free water, to analyze a possible decontamination. Experimental conditions in terms of feeding, photoperiod and physico-chemical values were the same as for the bioconcentration kinetics experiment. Moreover, to avoid a possible recontamination of individuals, water was renewed every 3 days. Five crayfishes per condition were collected after 1, 2, 8 and 20 days of depuration. The abdominal muscle was dissected, weighed and stored at $-20^{\circ} \mathrm{C}$ until CLD analysis. Only for aquaria where crayfish initially exposed to $2 \mu \mathrm{g} . \mathrm{L}^{-1}$ of CLD were placed, the CLD concentration was measured at day 1 and day 3 to quantify a possible CLD release in the depuration water (Table 1 ).

\section{Table 1}

Comparison of nominal values of the different treatments run during the experiments with the mean measured values, performed by the Laboratoire Territorial d'Analyses de Martinique. One water sampling per aquarium, in 3 different aquaria (3 replicates) per condition was done.

\begin{tabular}{lll}
\hline Treatment & $\begin{array}{l}\text { Nominal } \\
\text { value }\left(\mu \mathrm{g} . \mathrm{L}^{-1}\right)\end{array}$ & $\begin{array}{l}\text { Mean value }\left(\mu \mathrm{g} . \mathrm{L}^{-1}\right) \pm \text { Standard } \\
\text { deviation }\end{array}$ \\
\hline Control & 0 & $<0.01^{\mathrm{a}}$ \\
$\mathrm{C} 1$ & 0.2 & $0.23 \pm 0.03$ \\
$\mathrm{C} 2$ & 2 & $2.75 \pm 0.21$ \\
1 day-depuration & - & $0.02 \pm 0.003$ \\
3 day-depuration & - & $0.06 \pm 0.02$ \\
\hline
\end{tabular}

${ }^{\text {a }} 0.01 \mu \mathrm{g} . \mathrm{L}^{-1}$ representing the Limit of Detection of chlordecone. 


\subsection{Chlordecone concentration analysis}

CLD concentration in C. quadricarinatus muscles was analyzed according to the protocol detailed in Lafontaine et al. (2017a). Briefly, muscles were freeze-dried and an average of $250 \mathrm{mg}$ of lyophilized samples were used to CLD extraction, which was performed in Accelerated Solvent Extraction (ASE) with a mixture of $n$-hexane:dichloromethane (90:10; v:v; Biosolve-Chimie, France). After fat fraction extraction, samples were evaporated, resuspended in $2 \mathrm{~mL}$ hexane, and purified with a volume of $2 \mathrm{~mL} \mathrm{98 \%} \mathrm{sulfuric} \mathrm{acid,} \mathrm{used} \mathrm{to} \mathrm{remove}$ organic matter. Then, a 3-min centrifugation at $3000 \mathrm{rpm}$ allowed recovery of the organic layer, which was evaporated under gentle nitrogen flow. Finally, the extract was resuspended with $50 \mu \mathrm{L} n$-hexane and 50 $\mu \mathrm{L}$ of a solution PCB $209(100 \mathrm{pg} / \mu \mathrm{L}$ in $n$-hexane $)$ as an injection internal injection standard.

A procedural blank and a Quality Control were analyzed alongside the samples. The procedural blank consisted of ASE extraction without biological matrix, while the Quality Control consisted of ASE extraction with biological matrix (i.e. Cherax quadricarinatus muscle, CLD-free) spiked with CLD solution to obtain a final concentration of $2.5 \mathrm{ng} \mathrm{g}^{-1}$ wet weight.

CLD concentrations were analyzed in GC-ECD (Thermo Scientific, USA) using the parameters described in Lafontaine et al. (2017a). The limit of detection (LOD) was fixed at $0.02 \mathrm{ng} / \mathrm{g}$ wet weight (i.e. three times the background noise of chromatogram) and the limit of quantification was $0.06 \mathrm{ng} / \mathrm{g}$ wet weight. All CLD concentrations were expressed as ng.g ${ }^{-1}$ wet weight.

\subsection{CLD uptake and depuration rate constants}

The toxicokinetic model was done according to the OECD 305 Fish Bioconcentration Guidelines (OECD, Test No. 305), with some adaptations because our experimental design does not allow consideration of the fecal and gill elimination constants. Thus, to estimate the uptake rate constant $\left(\mathrm{k}_{1}\right)$ and the depuration rate constant $\left(\mathrm{k}_{2}\right)$, we assumed that CLD bioconcentration followed a first order kinetics. With this hypothesis, a linear model was obtained, and the depuration rate constant $\left(\mathrm{k}_{2}\right)$ correspond to the slope of equation (1):

$\ln \left(\mathrm{CLD}_{\mathrm{Cq}}\right)=-\mathrm{k}_{2} \cdot \mathrm{t}+\mathrm{c}$

with $\ln \left(\mathrm{CLD}_{\mathrm{Cq}}\right)$ the natural logarithm of the CLD amount in C. quadricarinatus muscle (ng), $\mathrm{k}_{2}$ the depuration rate constant and $\mathrm{c}$ the intercept, corresponding to the natural logarithm of the CLD concentration in C. quadricarinatus muscle (ng. $\mathrm{g}^{-1}$ ) at the end of the accumulation phase (i.e. start of the depuration phase). As the experiment time was relatively short (40 days in total), we considered no growth variation, and therefore the depuration rate constant was not corrected for organism growth. The uptake rate constant $\left(\mathrm{k}_{1}\right)$ can be estimated from $\mathrm{k}_{2}$ with this equation (2):

$\mathrm{C}_{\mathrm{Cq}}=\mathrm{CW} \cdot \frac{k 1}{k 2} \cdot\left(1-\mathrm{e}^{-\mathrm{k} 2 \cdot t}\right)$

with $\mathrm{C}_{\mathrm{Cq}}$ the concentration of CLD in the organism (ng. $\mathrm{g}^{-1}$ ), Cw the concentration of CLD in the exposure medium $\left(\mu \mathrm{g} . \mathrm{L}^{-1}\right)$ and $\mathrm{t}$ the time in days.

Finally, the bioconcentration factor (BCF) can be estimated using equation (3):

$B C F=\frac{k 1}{k 2}$

Finally, the depuration rate constant $\left(\mathrm{k}_{2}\right)$ was used to determine the time of depuration phase necessary to reach (or be) under the MRL (i.e. $20 \mathrm{ng} \mathrm{g}^{-1}$ ) in the muscle of $C$. quadricarinatus. For that, estimation was performed with equation (4):

$\mathrm{C}_{\mathrm{Cq}}=\mathrm{C}_{\mathrm{Cq}} 0 \cdot \mathrm{e}^{-\mathrm{k} 2 \cdot \mathrm{t}}$ where $\mathrm{C}_{\mathrm{Cq}}$ equals $20 \mathrm{ng} \mathrm{g}^{-1}$ and $\mathrm{C}_{\mathrm{Cq}} 0$ corresponding to the mean CLD concentration in the muscle tissue at the end of the bioconcentration phase (i.e. $15.91 \pm 7.44 \mathrm{ng} \mathrm{g}^{-1}$ for the $\mathrm{C} 1$ treatment and $91.19 \pm 20.73$ $\mathrm{ng} \mathrm{\textrm {g } ^ { - 1 }}$ for the C2 treatment). Similarly, half-life of CLD in the muscle tissue was calculated, for each condition using equation (5):

$\mathrm{T}_{1 / 2}=\ln (2) / \mathrm{k}_{2}$

with $\mathrm{T}_{1 / 2}$ corresponding to the half-life of CLD and $\mathrm{k}_{2}$ the depuration rate constant.

From equation (4) and using $\mathrm{k}_{2}$ of each exposure conditions, theoretical values of CLD concentration at each sampling time of depuration can be calculated. For that, $C_{C q 0}$ correspond to the mean CLD concentration measured in the crayfish muscle at the end of the accumulation phase (91.19 $\mathrm{ng} \mathrm{g}^{-1}$ for $2 \mu \mathrm{g} / \mathrm{L}$ exposure and $15.91 \mathrm{ng} \mathrm{g}^{-1}$ for $0.2 \mu \mathrm{g} / \mathrm{L}$ exposure), $\mathrm{k}_{2}$ to the depuration rate constant for each condition $(0.007$ for $0.2 \mu \mathrm{g} / \mathrm{L}$ exposure and 0.03 for $2 \mu \mathrm{g} / \mathrm{L}$ ) and t to each sampling time, during the depuration experiment. Thus, these theoretical values can be compared with the measured ones.

\subsection{Statistical analysis}

Statistical analyses were all performed using RStudio v1.1.463 (Core Team R Development, 2019). Normality and homogeneity of variance were tested with Shapiro and Bartlett tests $(p>0.05)$. The effect of the exposure time and CLD concentrations of exposure on the concentration measured in $C$. quadricarinatus muscle were analyzed with a two-way ANOVA, with a significant probability less than 0.05. Kruskal-Wallis test was performed on $k_{1}$ values, for each treatment, between each exposure time, to visualize a possible significative influence of the exposure time on the uptake rate constant. The same tests were used on the CLD concentration, to highlight the presence of different statistical groups between each treatment, at each exposure time. After that, each group were compared using a posthoc Kruskal test (Dunn's-test). A Generalized Linear Model (GLM) was used to investigate the correlation between the CLD concentration in the water (in-situ) and the CLD concentration in the crayfish tissues but also the influence of biotic parameters (body length and total weight) on the CLD bioconcentration in muscle. Student t-test and an Analyze of Variance were utilized to test respectively the difference of BCF between in lab-conditions and in-situ conditions.

\section{Results}

\subsection{CLD accumulation in crayfish wild population}

A significant positive correlation was observed between the CLD concentration in water and the CLD concentration accumulated in C. quadricarinatus muscle of wild populations $\left(\mathrm{R}^{2}=0.64\right.$; $\mathrm{p}$-value $<$ 0.001) (Fig. 2).

In the hatchery, where no CLD concentration was measured (i.e. below the LOD), the CLD concentration in the C. quadricarinatus muscle reached $0.13 \pm 0.12 \mathrm{ng} \mathrm{g}^{-1}$ while, at the most CLD-polluted station (i.e. Lezarde, with $2.48 \mu \mathrm{g} . \mathrm{L}^{-1}$ of CLD concentration all year round), the CLD concentration in the organism muscles reached $74.9 \pm 51.01 \mathrm{ng} \mathrm{g}^{-1}$ (with a bioconcentration factor of $30.21 \pm 20.58$ ). At the intermediate stations, Manzo (below quantification limit $0.03 \mu \mathrm{g} . \mathrm{L}^{-1}$ ) and Coulisses (mean $0.45 \mu \mathrm{g} . \mathrm{L}^{-1}$ all year round), the CLD concentrations measured in C. quadricarinatus muscles were $0.65 \pm 0.62 \mathrm{ng} \mathrm{g}^{-1}(21.52 \pm 20.71$ of bioconcentration factor) and $9.82 \pm 11.65 \mathrm{ng} \mathrm{g}^{-1}$ ( $22 \pm 26.12$ of bioconcentration factor), respectively (Table 2; Fig. 2). No significant difference was observed between the BCF estimated for each of the three contaminated stations $(\mathrm{F}=0.4$; $\mathrm{p}$-value $=0.54$ ). 


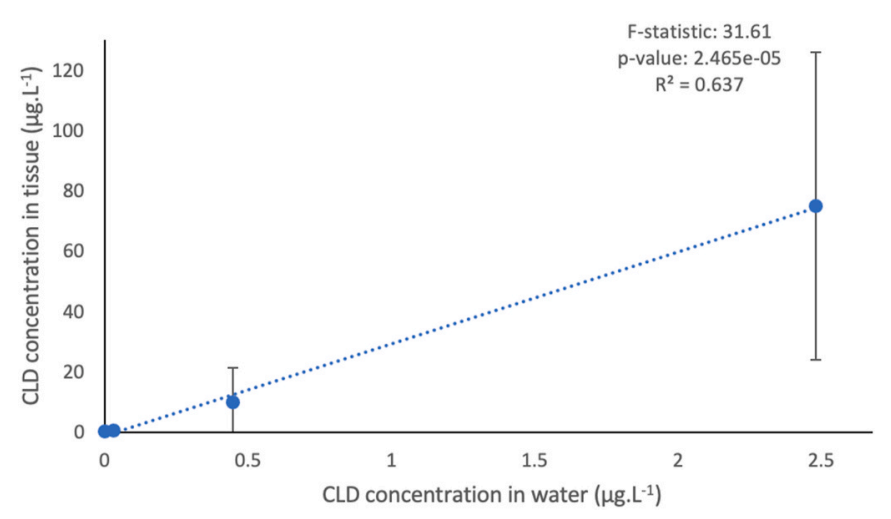

Fig. 2. Changes in CLD concentration (ng. $\mathrm{g}^{-1}$ ) in the Cherax quadricarinatus muscle (captured in the wild) depending on CLD concentration measured in the river water $\left(\mu \mathrm{g} . \mathrm{L}^{-1}\right)$.

\subsection{Short term exposure (lab experiment)}

\subsubsection{Kinetics of bioconcentration}

The real CLD concentrations, measured in the exposure medium, were close to the nominal values: $0.23 \pm 0.03 \mu \mathrm{g} . \mathrm{L}^{-1}$ against $0.2 \mu \mathrm{g} . \mathrm{L}^{-1}$ and $2.75 \pm 0.21 \mu \mathrm{g} . \mathrm{L}^{-1}$ against $2 \mu \mathrm{g} . \mathrm{L}^{-1}$ (Table 1 ). As expected, no CLD was detected in the control condition.

The CLD concentration bioaccumulated in C. quadricarinatus muscle was significantly influenced by both time of exposure and CLD concentration of exposure (Table 3 ) but not by body length of crayfish $\left(\mathrm{R}^{2}\right.$ : 0.007 , p-value: 0.75$)$ nor by crayfish weight $\left(R^{2}:-0.007\right.$, p-value: 0.84$)$ (Fig. 3). At the end of exposure (20 days), the mean CLD concentrations measured were $15.91 \pm 7.44 \mathrm{ng} \mathrm{g}^{-1}$ for $0.2 \mu \mathrm{g} . \mathrm{L}^{-1}$ condition and 91.19 $\pm 20.73 \mathrm{ng} \mathrm{g}^{-1}$ for $2 \mu \mathrm{g} . \mathrm{L}^{-1}$ treatment (Fig. 4). The CLD concentration in muscle of the crayfish control group reached $1.47 \pm 1 \mathrm{ng} \mathrm{g}^{-1}$ (Fig. 4). Results highlighted also that CLD concentrations measured in muscle were over the LOD and LOQ from $6 \mathrm{~h}$ of exposure, regardless the exposure condition (Fig. 4).

Values of $\mathrm{k}_{1}$ (uptake rate constant) were calculated at each sampling time for both exposure conditions (Fig. 5). For the $0.2 \mu \mathrm{g} . \mathrm{L}^{-1}$ treatment, the maximal $\mathrm{k}_{1}$ value $\left(10.27 \pm 2.93 \mathrm{~L} \mathrm{~kg}^{-1} \mathrm{~d}^{-1}\right)$ was observed after $6 \mathrm{~h}$ of CLD exposure, then it decreased to reach a plateau around $3 \mathrm{~L} \mathrm{~kg}^{-1} \mathrm{~d}^{-1}$ until the end of the exposure (Fig. 5). For the $2 \mu \mathrm{g} . \mathrm{L}^{-1}$ treatment, the same trend was observed, except that the maximal $\mathrm{k}_{1}$ value $(3.29 \pm 0.38$ $\mathrm{L} \mathrm{kg}^{-1} \mathrm{~d}^{-1}$ ) was estimated for the 6th day of exposure (Fig. 5).

BCF values, at the end of the absorption phase, showed that individuals exposed to the lowest CLD concentration (i.e. $0.2 \mu \mathrm{g} . \mathrm{L}^{-1}$ ) had the highest bioconcentration factor: $560.3 \pm 464.3$ and $67.4 \pm 29.9$ for the $0.2 \mu \mathrm{g} . \mathrm{L}^{-1}$ and the $2 \mu \mathrm{g} . \mathrm{L}^{-1}$ treatments, respectively (Table 2) highlighting a significant difference between the two conditions $(\mathrm{t}=$ 2.59 , $\mathrm{p}$-value $=0.04$ ).

\subsubsection{Depuration}

Depuration rate constants $\left(\mathrm{k}_{2}\right)$ reached respectively 0.007 days ${ }^{-1}$ (for $0.2 \mu \mathrm{g} . \mathrm{L}^{-1}$ condition) and 0.03 days $^{-1}$ (for $2 \mu \mathrm{g} . \mathrm{L}^{-1}$ condition).

After 20 days of depuration, a very low decrease of CLD concentration in muscle was observed for crayfish exposed at $0.2 \mu \mathrm{g} . \mathrm{L}^{-1}$ : the CLD concentration reached $10.8 \pm 6.26 \mathrm{ng} \mathrm{g}^{-1}$, corresponding to a $32.12 \%$ loss (CLD concentration at the end of bioconcentration period was $15.91 \pm 7.44 \mathrm{ng} \mathrm{g}^{-1}$ ) (Fig. 4). This maximum time of depuration tested seemed to reduce the CLD concentration in muscle, even though it was already below the MRL at the end of the exposure time.

For C. quadricarinatus exposed to $2 \mu \mathrm{g} . \mathrm{L}^{-1}$, no decrease in CLD concentration was observed during the six first days. Then, a slow decrease

Table 3

Two-way Analysis of Variance (ANOVA) investigating the effects of exposure time to CLD (Time) and the CLD concentration of exposure (Medium) on the CLD concentration bioaccumulated in Cherax quadricarinatus muscle.

\begin{tabular}{lllll}
\hline Source of variation & Sum of square & d.f. & $F$ & $p$-Values \\
\hline Time & 20472 & 5 & 31.88 & $<0.001$ \\
Medium & 10319 & 1 & 80.36 & $<0.001$ \\
Time x Medium & 10550 & 5 & 16.43 & $<0.001$ \\
Residuals & 5650 & 44 & & \\
\hline
\end{tabular}
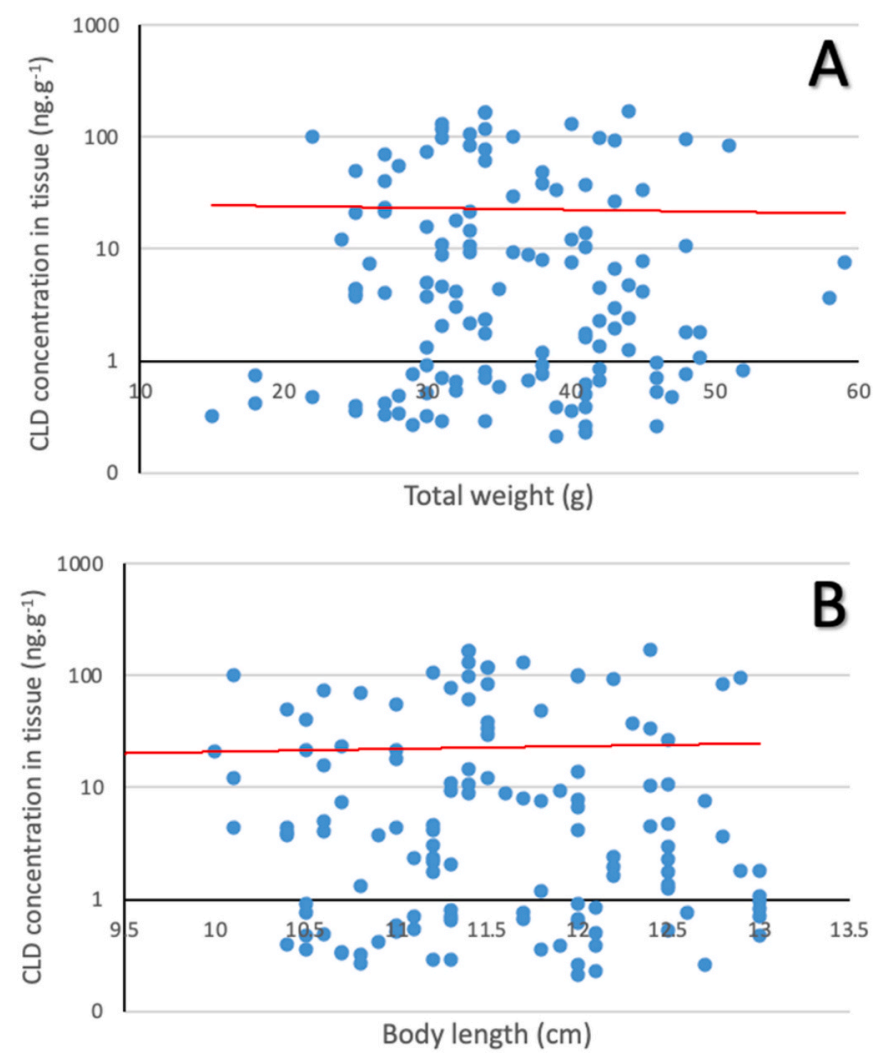

Fig. 3. Influence of total weight (A) and total body length (B) of the crayfish on CLD concentration measured in the muscle of Cherax quadricarinatus, using a Generalized Linear Model (GLM). Neither of the two parameters seems to be significant (respectively for A: $\mathrm{R}^{2}:-0.007$, p-value: 0.84 and $\mathrm{B}: \mathrm{R}^{2}: 0.007$, value: 0.75$)$.

Table 2

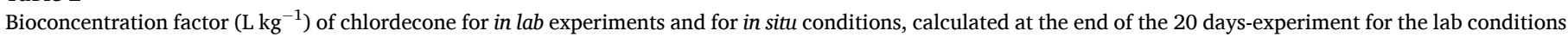

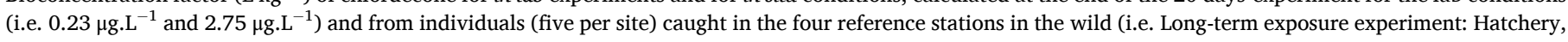

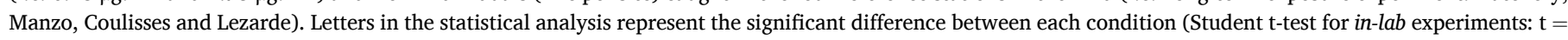
2.59 , p-value $=0.04$; and ANOVA for in situ experiments: $\mathrm{F}=0.4$; $\mathrm{p}$-value $=0.54$ ).

\begin{tabular}{|c|c|c|c|c|c|c|}
\hline & \multicolumn{2}{|l|}{ In lab } & \multicolumn{4}{|l|}{ In situ } \\
\hline & & & Hatchery & Manzo & Coulisses & Lezarde \\
\hline Measured CLD concentration & $0.23 \mu \mathrm{g} . \mathrm{L}^{-1}$ & $2.75 \mu \mathrm{g} . \mathrm{L}^{-1}$ & $<$ LOD & $<0.03 \mu \mathrm{g} . \mathrm{L}^{-1}$ & $0.45 \mu \mathrm{g} . \mathrm{L}^{-1}$ & $2.48 \mu \mathrm{g} . \mathrm{L}^{-1}$ \\
\hline $\mathrm{BCF}$ & $560.3 \pm 464.3^{\mathrm{A}}$ & $67.4 \pm 29.9^{\mathrm{B}}$ & - & $21.52 \pm 20.71^{\mathrm{A}}$ & $22 \pm 26.12^{\mathrm{A}}$ & $30.21 \pm 20.58^{\mathrm{A}}$ \\
\hline
\end{tabular}




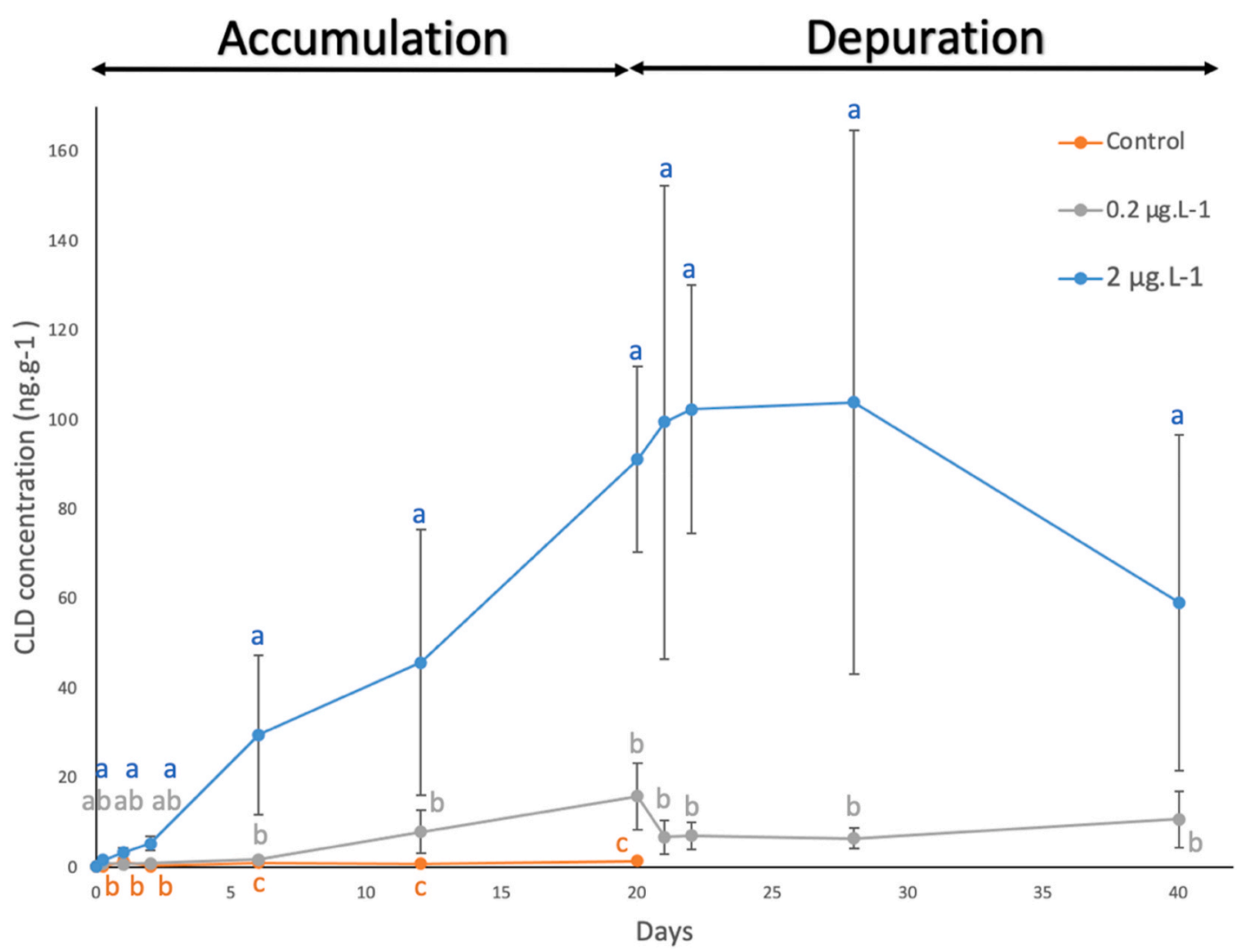

Fig. 4. Accumulation and depuration phases of CLD in the Cherax quadricarinatus muscle for the two exposure conditions tested ( $0.2 \mu \mathrm{g} . \mathrm{L}^{-1}$ chlordecone exposition condition in orange and $2 \mu \mathrm{g} . \mathrm{L}^{-1}$ in grey). Depuration was done by placing crayfish in CLD-free water during 20 days with a renewal of the water every 3 days. Letters represent the statistical differences between each condition at each time, following Kruskal-Wallis and posthoc tests. (For interpretation of the references to colour in this figure legend, the reader is referred to the Web version of this article.)

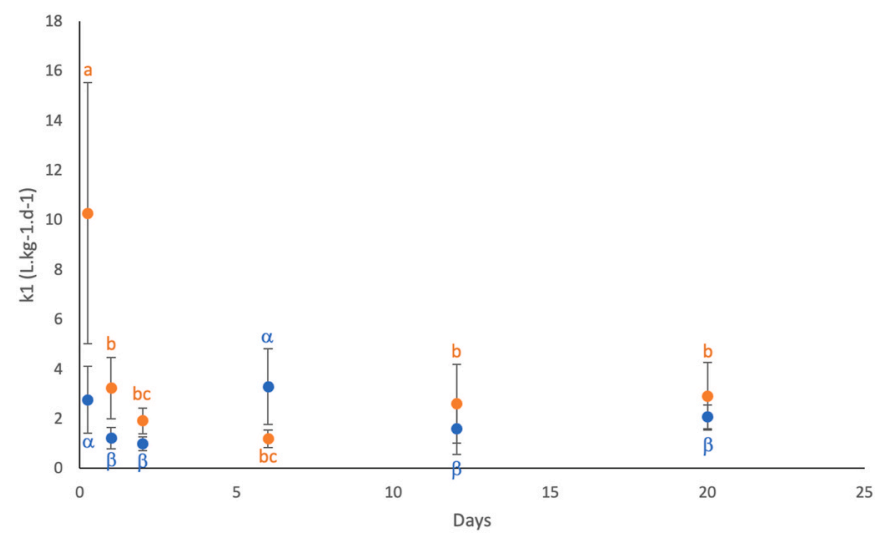

Fig. 5. Variation of the constant accumulation rate $\left(\mathrm{k}_{1}\right)$ for Cherax quadricarinatus, calculated from the constant elimination rate $\mathrm{k}_{2}$, over time, for the $0.2 \mu \mathrm{g} . \mathrm{L}^{-1} \mathrm{CLD}$ exposition condition (orange dot) and the $2 \mu \mathrm{g} . \mathrm{L}^{-1}$ chlordecone exposition condition (blue dot). Letters represents the different statistical groups between each exposure time, for each condition. (For interpretation of the references to colour in this figure legend, the reader is referred to the Web version of this article.)

was measured and CLD concentration reached $59.18 \pm 37.47 \mathrm{ng} \mathrm{g}^{-1}$ at the end of the decontamination period, corresponding to a $35.1 \%$ loss (CLD concentration at the end of the bioconcentration period was 91.19 $\pm 20.73 \mathrm{ng} \mathrm{g}^{-1}$ ) (Fig. 4). This CLD concentration at the end of the depuration phase was always higher than the MRL, however, according to calculations from uptake and elimination constants, 50.57 days seems necessary to reach the MRL $\left(20 \mathrm{ng} \mathrm{g}^{-1}\right)$ in muscle of crayfish exposed for
20 days at $2 \mu \mathrm{g} \cdot \mathrm{L}^{-1}$.

The half-life of CLD in the muscle tissue is 99 days for the $0.2 \mu \mathrm{g} . \mathrm{L}^{-1}$ condition and 23.1 days for the $2 \mu \mathrm{g} . \mathrm{L}^{-1}$ condition.

For the $0.2 \mu \mathrm{g} . \mathrm{L}^{-1}$ of CLD exposure condition, the mean measured values of CLD in the crayfish muscle are below the theoretical values at each depuration time, with an increase of the CLD concentration at Day 20 (6.8 $\mathrm{ng} \mathrm{g}^{-1}$ at Day 1 and $10.1 \mathrm{ng} \mathrm{g}^{-1}$ at Day 20 for the measured values vs $15.8 \mathrm{ng} \mathrm{g}^{-1}$ at Day 1 and $13.8 \mathrm{ng} \mathrm{g}^{-1}$ at Day 20) (Table 4).

For the $2 \mu \mathrm{g} . \mathrm{L}^{-1}$ of CLD exposure condition, the mean measured values raise until day 8 (82.9 $\mathrm{ng} \mathrm{g}^{-1}$ at Day $1-103.9 \mathrm{ng} \mathrm{g}^{-1}$ at Day 8 ) and are above the theoretical values for the Day 2 and Day 8 of depuration. After that the mean CLD measured values decrease until Day 20 and reach $59.8 \mathrm{ng} \mathrm{g}^{-1}$, close to the theoretical value calculated $\left(50.1 \mathrm{ng} \mathrm{g}^{-1}\right)$ (Table 4).

Finally, the CLD concentration measurements in water, after 1 and 3

Table 4

Comparison of theoretical values of CLD concentration in crayfish muscle at each sampling time during the depuration experiment, for each condition, based on calculations with equation (4) and the respective $k_{2}$ values, with the measured values.

\begin{tabular}{|c|c|c|c|c|}
\hline & \multicolumn{2}{|c|}{$\begin{array}{l}0.2 \mu \mathrm{g} . \mathrm{L}^{-1} \text { of CLD exposure } \\
\text { condition }\end{array}$} & \multicolumn{2}{|c|}{$\begin{array}{l}2 \mu \mathrm{g} . \mathrm{L}^{-1} \text { of CLD exposure } \\
\text { condition }\end{array}$} \\
\hline & $\begin{array}{l}\text { Theoretical } \\
\text { values } \\
\left(\text { ng. } g^{-1}\right)\end{array}$ & $\begin{array}{l}\text { Measured } \\
\text { values } \\
\left(\text { ng. } g^{-1}\right)\end{array}$ & $\begin{array}{l}\text { Theoretical } \\
\text { values } \\
\left(\text { ng. } g^{-1}\right)\end{array}$ & $\begin{array}{l}\text { Measured } \\
\text { values } \\
\left(\mathrm{ng} \cdot \mathrm{g}^{-1}\right)\end{array}$ \\
\hline Day 1 & 15.8 & 6.8 & 88.5 & 82.9 \\
\hline Day 2 & 15.7 & 7.1 & 85.9 & 102.4 \\
\hline Day 8 & 15 & 6.5 & 71.7 & 103.9 \\
\hline Day 20 & 13.8 & 10.1 & 50.1 & 59.2 \\
\hline
\end{tabular}


days of depuration (for crayfish initially exposed to $2 \mu \mathrm{g} . \mathrm{L}^{-1}$ of CLD), revealed an increase of CLD in the water over time: $0.02 \pm 0.003 \mu \mathrm{g} . \mathrm{L}^{-1}$ at Day 1 and $0.06 \pm 0.02 \mu \mathrm{g} . \mathrm{L}^{-1}$ at Day 3 (Table 1 ).

\section{Discussion}

\subsection{CLD in wild crayfish populations}

The CLD concentration analysis in muscle of $C$. quadricarinatus wild population highlighted a significant positive correlation between the CLD concentration in river water and the CLD concentration bioaccumulated in organisms. This trend is consistent with several studies showing bioaccumulation of CLD in aquatic organisms like fish or crustaceans. Coat et al. (2006) showed CLD concentrations ranging from $196 \mathrm{ng} \mathrm{g}^{-1}$ and $386 \mathrm{ng} \mathrm{g}^{-1}$ in the whole body of Oreochromis mossambicus sampled in the Lezarde river in Martinique. Monti (2007) highlighted more impressive CLD bioaccumulation rates in aquatic organisms sampled in the Grande Anse river (Guadeloupe, French West Indies), contaminated at $1.715 \mu \mathrm{g} . \mathrm{L}^{-1} \mathrm{CLD}$ : from $1568 \mathrm{ng} \mathrm{g}^{-1}$ to 4002 $\mathrm{ng} \mathrm{g}^{-1}$ for the crustaceans Atya innocuous and Xiphocaris elongata, respectively, and up to $11,733 \mathrm{ng} \mathrm{g}^{-1}$ for the freshwater fish Eleotris perniger. These higher CLD bioconcentrations, as compared to the present study, seem to be due to the fact that CLD analysis was carried out in the whole-body organisms and not only using the muscle as in our study. This assumption was confirmed by Lafontaine et al. (2017b) who investigated the CLD distribution in the prawn M. rosenbergii. The authors observed that the CLD was mainly distributed in the hepatopancreas (i.e. detoxification tissue) (between 50 and 65\% of the total CLD amount) and less in the muscle (between 15 and $20 \%$ of the total CLD amount).

\subsection{CLD behaviour under in-vitro conditions}

The laboratory approach was carried out to better evaluate the CLD toxicokinetic mechanism in the invasive crayfish C. quadricarinatus. Results highlighted that although CLD concentration in control conditions was below the LOD, a low concentration of CLD was measured in the muscle $\left(1.47 \pm 1 \mathrm{ng} \mathrm{g}^{-1}\right)$, thus confirming a much higher BCF calculated for a lower CLD concentration exposure. The same result was observed in the CLD analysis in wild populations, where C. quadricarinatus sampled in Manzo (CLD concentration $<0.03 \mu \mathrm{g} / \mathrm{L}$ ) were contaminated by measurable CLD concentration. These results confirmed the fact that the analysis of xenobiotic bioconcentration in biota could reinforce the biomonitoring of aquatic ecosystem contaminations. Besides, a rapid CLD absorption in C. quadricarinatus muscle happened from the first exposure time $(6 \mathrm{~h})$, whatever the condition (i.e. $0.2 \mu \mathrm{g} . \mathrm{L}^{-1}$ and $2 \mu \mathrm{g} . \mathrm{L}^{-1}$ ). This is consistent with the fact that the higher $\mathrm{k}_{1}$ was estimated at the beginning of the bioconcentration phase, as also observed in the prawn M. rosenbergii (Lafontaine et al., 2017b). Even if these results are in accordance with other studies, they must be considered with cautious due to the fact that the steady-state, recommended for a BCF calculation, was not reached in our study.

The kinetic results showed a significant positive influence of exposure time and CLD concentration on the CLD bioaccumulated in the muscle. These findings are in accordance with other studies, such as Lafontaine et al. (2017a, 2017b) who highlighted a quick accumulation of CLD (measurable as early as $6 \mathrm{~h}$ ), in the prawn $M$. rosenbergii whole body, and a slow-down after 4 days of exposure: the uptake rate is lower after this time (and so, the accumulation of pollutant) but the saturation (plateau phase) seems to be not reached (Lafontaine et al., 2017b), as for C. quadricarinatus in our study. These results could be explained by the fact that the muscle bioconcentrates CLD slower than other organs like the hepatopancreas. Even if the plateau seems not be reached, we reached CLD concentration close to those measured in the muscle of crayfish caught in the wild, exposed to CLD for longer. This leads us to believe that this accumulation occurs throughout life without reaching stabilization or that this plateau phase would have been reached with a longer exposure. Relatively similar trends were found in terrestrial vertebrates: a great and quick assimilation of CLD was observed in goat and in cows matrices (Lastel et al., 2016; Fournier et al., 2017 and references therein). Concerning the depuration of goat matrices studied by Lastel et al. (2016), contaminated with CLD at $1 \mathrm{mg} \mathrm{kg}^{-1}$ body weight, a steady-state was observed after the accumulation phase and so, a delay before an efficient elimination of the CLD, fitting with our results. Interestingly, a relatively close half-life was found between our two experiments ( 20 days vs 23.1 days). Contrarily, for the muscle of beef, contaminated with CLD at $1 \mathrm{mg} \mathrm{kg}^{-1}$ body weight, the half-life of CLD reach 43 days. The accumulation and depuration were both linked to the physiological status and the metabolic capacities explaining why certain taxonomic groups accumulate more efficiently the CLD through their feeding habits and eliminate more or less efficiently the pollutants than other (via lactation or eggs laying for example) (Lastel et al., 2016 and references therein).

Interestingly, results obtained in the laboratory experiment highlighted a similar pattern to that of wild individuals, showing a dosedependent accumulation of CLD (i.e. higher CLD concentration in muscles of crayfish sampled in rivers highly contaminated): $15.91 \pm$ $7.44 \mathrm{ng} \mathrm{g}^{-1}$ for $0.2 \mu \mathrm{g} . \mathrm{L}^{-1}$ treatment against $9.82 \pm 11.65 \mathrm{ng} \mathrm{g}^{-1}$ for Coulisses river (mean 0.45 $\mu \mathrm{g} . \mathrm{L}^{-1}$ all year) and $91.19 \pm 20.73 \mathrm{ng} \mathrm{g}^{-1}$ for $2 \mu \mathrm{g} . \mathrm{L}^{-1}$ treatment against $74.9 \pm 51.01 \mathrm{ng} \mathrm{g}^{-1}$ for Lezarde river $(2.48$ $\mu \mathrm{g} . \mathrm{L}^{-1}$ of CLD concentration all year).

Higher levels of CLD contamination were expected in specimens caught in-situ. Indeed, absorption via both water and food, contaminated at a lower level, is known to be more efficient (Bahner et al., 1977). This is accentuated in the case of our study, as like the majority of invasive crayfish, C. quadricarinatus is omnivorous and opportunistic, capable of predating on macroinvertebrates, and therefore, placed quite high in the trophic chain (Johnston et al., 2011; Jackson et al., 2017) and so, becoming more contaminated than other species at a lower level. Hoekstra et al. (2003) highlighted that large mammals were more contaminated than fish, themselves more contaminated than copepods. Although laboratory experiments highlighting only CLD bioconcentration from water, the CLD concentration measured in crayfish caught in-situ seems to be more realistic. This slight difference, less contaminated individuals in the wild, can be explained by the fact that the toxicokinetic constants remains more difficult to estimate in the natural environment because it is necessary to take into account many environmental factors (season, temperature, dissolved oxygen, turbidity, predation, cocktail effect of different pollutants ...) (Rotchell and Ostrander, 2003).

Some studies highlighted the possibility for invertebrates to eliminate the CLD (more or less quickly) from their own body, partly via their faeces, moulting (Bahner et al., 1977) or other unknown mechanisms (Schimmel et al., 1977; Lafontaine et al., 2017a, 2017b). Here, we highlighted values of CLD concentration in the crayfish just below the MRL for individuals exposed to $0.2 \mu \mathrm{g} . \mathrm{L}^{-1}$ for 20 days (15.91 $\pm 7.44 \mathrm{ng}$ $\mathrm{g}^{-1}$ at the end of the 20 days-absorption phase against $20 \mathrm{ng} \mathrm{g}^{-1}$ for the MRL). But those exposed to higher concentrations were contaminated above this value. Unfortunately, a very slow CLD decontamination was observed in the $C$. quadricarinatus muscle for the $2 \mu \mathrm{g} . \mathrm{L}^{-1}$ treatment, or even an absence of decontamination for the $0.2 \mu \mathrm{g} . \mathrm{L}^{-1}$ treatment. Based on the depuration constant $\mathrm{k}_{2}$ determined in this work $\left(0.03\right.$ days $\left.{ }^{-1}\right)$, 50.57 days of depuration seem necessary to reach the MRL in muscle of crayfish exposed for 20 days at $2 \mu \mathrm{g} . \mathrm{L}^{-1}$. This can be explained by the fact that the muscle was not very efficient at eliminating the CLD. This time was not possible to be estimated in organisms exposed to $0.2 \mu \mathrm{g} . \mathrm{L}^{-1}$ because CLD concentration at the end of the bioconcentration period was already below the MRL. Indeed, previous studies showing CLD depuration, used the entire body, including the hepatopancreas, known to play an important role in the accumulation, detoxification of pollutants in crustaceans (Lafontaine et al., 2017a, 2017b) and their elimination (Sreeram and Menon, 2005; Zeng et al., 2010). The depuration 
observed in M. rosenbergii by Lafontaine et al. (2017a, 2017b) may be mainly due to the detoxification of CLD by the hepatopancreas. However, other detoxification system could explain this observation such as the MXR (e.g. multi-xenobiotics resistance mechanism) pump system, protecting aquatic species against pollutant molecules (Kurelec, 1992), as already investigated in other aquatic invertebrates (i.e. bivalves and crustaceans) (Pain and Parant, 2007; Horion et al., 2015). This MXR system could explain the fact that CLD concentration decreased in the organism and increased in the water over time during the depuration phase, until the renewal at day 3. This release of CLD into the depuration water reinforces the idea that it is not sufficient to simply place the organisms in clean water to allow them to be decontaminated within a defined period, but that it is necessary to renew the medium at least every three days, to avoid possible recontamination of exposed individuals. Another explanation can be a contamination due to traces of pollutant present on the crayfish cuticle after the accumulation period but all the precautions were taken (i.e. thorough washing of crayfish before the transfer in the CLD-free for the depuration period). However, this depuration system seems to be ineffective at quickly reaching the MRL in crayfish muscle. In fact, it cannot be excluded that the presence of CLD in the depuration water could led to a recontamination of the organisms, especially because our results highlight that crayfish didn't reach the steady-state of bioconcentration, and we observed an increase of the CLD muscle concentration measured even during the first time of depuration. This suggests that CLD released in water, even if at a very low concentration, could be uptake again by organisms. This hypothesis is supported by the in-situ experiment showing a CLD bioconcentration in crayfishes sampled in the Manzo river, having a similar CLD concentration as the depuration water (i.e. 0.03 ng. $\mathrm{L}^{-1}$ ). This could therefore also explain the low estimated $\mathrm{k}_{2}$ after the depuration phase.

However, as our results doesn't really show a depuration, these theoretical calculations could be more accurate in the case of a longer depuration which could show a real decrease of CLD in the body. However, the muscle is not a detoxifying organ and so, we are not sur that a longer depuration time would result in a depuration of CLD from the muscle and the CLD concentration could remain the same in the long term.

\subsection{Risks for consumers}

This rapid and high CLD accumulation in combination with an inefficient CLD decontamination of the muscle could pose a human health problem: even if fishing in the Martinican rivers is prohibited, this recreational and ancestral practice remains very difficult to control. Many fishermen put traps in the rivers every day (Personal observation) to catch crustaceans for their personal consumption or to sell them on the markets. Moreover, this practice is also very lucrative: C. quadricarinatus can be sold for up to $25 € / \mathrm{kg}$ as it is considered a luxury gourmet product. This species is now found and fished in high densities in several martinican rivers (Baudry et al., 2021). The majority of rivers inhabit by C. quadricarinatus are polluted by CLD beyond the potability thresholds set by the Regional Health Agency $\left(0.1 \mu \mathrm{g} . \mathrm{L}^{-1}\right)$ or even well above $0.2 \mu \mathrm{g} . \mathrm{L}^{-1}$, which is an exposure concentration resulting in the MRL being exceeded in crayfish muscle, according to our study (Fig. 1).

Due to the transfer of CLD along the food chain, CLD can thus reach humans through the consumption of contaminated products. Even if a recent study, based on the analysis of CLD contamination before and after several cooking processes, highlighted a strike reduction of the amount of CLD in beef meat (Martin et al., 2020), exposure to CLD is now chronic and it is detectable in the blood of the majority of the Caribbean population (Multigner et al., 2007). This could generate a health problem since it has been shown that CLD could be responsible to the development of diseases, such as prostate cancer (Multigner et al., 2007). The possibility of cooking products previously decontaminated by a simple depuration period, as studied in this work, could have been an interesting alternative to the consumption of crayfish. But the fact that the muscle of $C$. quadricarinatus is only slowly decontaminated in CLD-free water means that other methods must be tested to allow the safe consumption of these products: a decontamination period longer than 20 days, in a tank, with potential losses of specimens due to cannibalism or inconvenience in an artificial closed environment (leading to mortality), is likely not to be followed by fishermen. At the moment, the most efficient way of stopping the spread of this poison is to inform the population on the dangers of this wild fishery. This social aspect is important as the problem is likely to persist for a very long time as modelling analyses have predicted that CLD in soils would persist for at least 300 years in Martinique (Cabidoche et al., 2009).

\section{Conclusion}

This study aimed to investigate the level of CLD contamination in C. quadricarinatus muscle of wild populations and determine the CLD toxicokinetic (i.e. bioconcentration and depuration) through in-vitro experiments in order to investigate the processes and to communicate about an alternative to consume these fishery products. Here, we showed a clear positive correlation between the CLD concentration in water and the CLD concentration measured in the muscle of crayfish caught in the wild. These results were in accordance with in-vitro experiments: a quick (as early as $6 \mathrm{~h}$ of exposure) and efficient bioconcentration over time, reaching approximatively $100 \mathrm{ng} \mathrm{g}^{-1}$ of CLD for crayfish exposed to $2 \mu \mathrm{g} . \mathrm{L}^{-1}$ of CLD and approximatively $20 \mathrm{ng} \mathrm{g}^{-1}$ (corresponding to the MRL) for crayfish exposed to $0.2 \mu \mathrm{g} . \mathrm{L}^{-1}$ was observed. Worryingly, we were not able to decontaminate the muscle of contaminated $C$. quadricarinatus: almost 3 weeks of decontamination did not reduce the concentration of CLD below the MRL for crayfish exposed $2 \mu \mathrm{g} . \mathrm{L}^{-1}$ CLD. The crayfish resource is inexhaustible in the natural environment as this invasive species seems not to be affected by this abiotic stressor, making the situation alarming: C. quadricarinatus is highly prized in Martinique and chlordecone, highly present in a majority of Martinique watersheds, is well known to cause significant health problems. Depuration experiments have shown that the muscle seems to decontaminate too slowly to propose this as an alternative for the consumption of products caught in the Martinique rivers.

\section{Credit Author Statement}

Thomas Baudry: Conceptualization, Methodology, Software, Formal analysis, Investigation, Data curation, Writing - original draft, Writing - review \& editing, Visualization, Validation, Project administration, Funding acquisition; Eric Gismondi: Conceptualization, Methodology, Formal analysis, Data curation, Writing - review \& editing, Visualization, Validation; Jean-Pierre Gout: Supervision, Writing review \& editing, Project administration, Funding acquisition; Alexandre Arqué: Supervision, Writing - review \& editing, Project administration, Funding acquisition; Juliette Smith-Ravin: Writing - review \& editing, Supervision, Project administration, Funding acquisition; Frédéric Grandjean: Conceptualization, Writing - review \& editing, Supervision, Project administration, Funding acquisition.

\section{Declaration of competing interest}

The authors declare that they have no known competing financial interests or personal relationships that could have appeared to influence the work reported in this paper.

\section{Acknowledgement}

We thank the Institut Français de Recherche pour l'Exploitation de la Mer (IFREMER) for welcoming us into their structure in order to carry out the experiments and the Laboratoire Territorial d'Analyses (LTA) de Martinique for having carried out the river water analyses. We also 
thank Catherine Adam, technician at the Laboratory of Animal Ecology and Ecotoxicology (LEAE) of the University of Liege, for the CLD analyses in the crayfish tissues.

We thank Julian Reynolds for reading the article and correcting the English.

This project was funded by the Direction de l'Environnement, de l'Aménagement et du Logement de Martinique (DEAL), the Office de l'Eau de Martinique (ODE), the ffice Français de la Biodiversité (OFB) and the Collectivité Territoriale de Martinique (CTM).

\section{References}

Azofeifa-Solano, J.C., Naranjo-Elizondo, B., Rojas-Carranza, A.H., Cedeño-Fonseca, M., 2017. Presence of the Australian redclaw crayfish Cherax quadricarinatus (von Martens, 1868) (Parastacidae, Astacoidea) in a freshwater system in the Caribbean drainage of Costa Rica. BioInvasions Records 6, 351-355. https://doi.org/10.3391/ bir.2017.6.4.08.

Bahner, L.H., Wilson, A.J., Sheppard, J.M., Patrick, J.M., Goodman, L.R., Walsh, G.E., 1977. Kepone ${ }^{\circledR}$ bioconcentration, accumulation, loss, and transfer through estuarine food chains. Chesap. Sci. 18, 299. https://doi.org/10.2307/1350804.

Baudry, T., Becking, T., Goût, J.P., Arqué, A., Gan, H.M., Austin, C.M., Delaunay, C., Smith-Ravin, J., Roques, J.A.C., Grandjean, F., 2020. Invasion and distribution of the redclaw crayfish, Cherax quadricarinatus, in Martinique. In: Knowledge and Management of Aquatic Ecosystems, vol. 421. https://doi.org/10.1051/kmae/ 2020041.

Baudry, T., Mauvisseau, Q., Goût, J., Arqué, A., Delaunay, C., Smith-ravin, J., Sweet, M., 2021. Mapping a super-invader in a biodiversity hotspot , an eDNA-based success story. Ecol. Indicat. 126 https://doi.org/10.1016/j.ecolind.2021.107637.

Cabidoche, Y., Achard, R., Cattan, P., Clermont-dauphin, C., Massat, F., Sansoulet, J., 2009. Long-term pollution by chlordecone of tropical volcanic soils in the French West Indies : a simple leaching model accounts for current residue. Environ. Pollut. 157, 1697-1705. https://doi.org/10.1016/j.envpol.2008.12.015.

Cabidoche, Y.M., Lesueur-Jannoyer, M., 2012. Contamination of harvested organs in root crops grown on. Pedosphere: Int. J. 22, 562-571. https://doi.org/10.1016/S10020160(12)60041-1.

Cannon, S.B., Veazey, James M., Jackson, Robert S., Virlyn, W., Hayes, Carl, Straub, Wesley E., Landrigan, Philip J., Liddle, J.A., Cdc, S.B., Veazey, J.M., Jackson, R.S., Burse, V.W., Hayes, C., Straub, W.E., Landrigan, P.J., Llddle, J.A., 1978. Epidemic kepone poisoning in chemical workers. Am. J. Epidemiol. 107, 529-537.

Coat, S., Bocquené, G., Godard, E., 2006. Contamination of some aquatic species with the organochlorine pesticide chlordecone in Martinique. Aquat. Living Resour. 19, 181-187. https://doi.org/10.1051/alr:2006016.

Core Team, R Development, 2019. R: a Language and Environment for Statistical Computing.

Crooks, J.A., Chang, A.L., Ruiz, G.M., 2011. Aquatic pollution increases the relative success of invasive species. Biol. Invasions 13, 165-176. https://doi.org/10.1007/ s10530-010-9799-3.

De Moor, I., 2002. Potential impacts of alien freshwater crayfish in South Africa. Afr. J. Aquat. Sci. 125-139. https://doi.org/10.2989/16085914.2002.9626584.

FAO, 2016. Fishery and Aquaculture Statistics 2016.

Fedorenkova, A., Vonk, J.A., Breure, A.M., Hendriks, A.J., Leuven, R.S.E.W., 2013. Tolerance of native and non-native fish species to chemical stress: a case study for the River Rhine. Aquat. Invasions 8, 231-241. https://doi.org/10.3391/ ai.2013.8.2.10.

Filipová, L., Petrusek, A., Matasová, K., Delaunay, C., Grandjean, F., 2013. Prevalence of the crayfish plague pathogen Aphanomyces astaci in populations of the signal crayfish Pacifastacus leniusculus in France: evaluating the threat to native crayfish. PloS One 8, e70157. https://doi.org/10.1371/journal.pone.0070157.

Fournier, A., Feidt, C., Lastel, M.L., Archimede, H., Thome, J.P., Mahieu, M., Rychen, G. 2017. Toxicokinetics of chlordecone in goats: implications for risk management in French West Indies. Chemosphere 171, 564-570. https://doi.org/10.1016/j. chemosphere.2016.12.054

Hansen, D.J., Goodman, L.R., Wilson, A.J., 1977. Kepone ${ }^{\circledR}$ : chronic effects on embryo, fry, juvenile, and adult sheepshead minnows (Cyprinodon variegatus). Chesap. Sci. 18 227. https://doi.org/10.2307/1350865.

Hoekstra, P.F., O'Hara, T.M., Fisk, A.T., Borgå, K., Solomon, K.R., Muir, D.C.G., 2003. Trophic transfer of persistent organochlorine contaminants (OCs) within an Arctic marine food web from the southern Beaufort-Chukchi Seas. Environ. Pollut. 124, 509-522.

Horion, S., Thomé, J.P., Gismondi, É., 2015. Changes in antitoxic defense systems of the freshwater amphipod Gammarus pulex exposed to BDE-47 and BDE-99. Ecotoxicology 24, 959-966. https://doi.org/10.1007/s10646-015-1438-4.
Jackson, M.C., Evangelista, C., Zhao, T., Lecerf, A., Britton, J.R., Cucherousset, J., 2017. Between-lake variation in the trophic ecology of an invasive crayfish. Freshw. Biol. 62, 1501-1510. https://doi.org/10.1111/fwb.12957.

Johnston, K., Robson, B.J., Fairweather, P.G., 2011. Trophic positions of omnivores are not always flexible: evidence from four species of freshwater crayfish. Austral Ecol. https://doi.org/10.1111/j.1442-9993.2010.02147.x.

Jones, C., 1990. The Biology and Aquaculture Potential of the Tropical Freshwater Crayfish, Cherax quadricarinatus. Department of Primary Industries Queensland.

Kurelec, B., 1992. The multixenobiotic resistance mechanism in aquatic organisms. Critical Reviews in Toxicology. https://doi.org/10.3109/10408449209145320.

Lafontaine, A., Baiwir, D., Joaquim-justo, C., Pauw, E. De, Lemoine, S., Boulangélecomte, C., Forget-leray, J., Thomé, J., 2017a. Proteomic response of Macrobrachium rosenbergii hepatopancreas exposed to chlordecone : identification of endocrine disruption biomarkers? Ecotoxicol. Environ. Saf. 141, 306-314. https:// doi.org/10.1016/j.ecoenv.2017.03.043.

Lafontaine, A., Gismondi, E., Dodet, N., Caupos, F., Lemoine, S., Lagadic, L., 2017b. Bioaccumulation, distribution and elimination of chlordecone in the giant freshwater prawn Macrobrachium rosenbergii: field and laboratory studies. Chemosphere 185, 888-898. https://doi.org/10.1016/j.chemosphere.2017.07.099.

Lastel, M.L., Lerch, S., Fournier, A., Jurjanz, S., Mahieu, M., Archimède, H., Feidt, C., Rychen, G., 2016. Chlordecone disappearance in tissues of growing goats after a one month decontamination period-effect of body fatness on chlordecone retention. Environ. Sci. Pollut. Control Ser. 23, 3176-3183. https://doi.org/10.1007/s11356015-5833-4.

Martin, D., Lobo, F., Lavison-Bompard, G., Guérin, T., Parinet, J., 2020. Effect of home cooking processes on chlordecone content in beef and investigation of its byproducts and metabolites by HPLC-HRMS/MS. Environ. Int. 144, 106077. https:// doi.org/10.1016/j.envint.2020.106077.

Merlin, C., Devers, M., Béguet, J., Boggio, B., Rouard, N., Martin-Laurent, F., 2016. Evaluation of the ecotoxicological impact of the organochlorine chlordecone on soil microbial community structure, abundance, and function. Environ. Sci. Pollut. Control Ser. 23, 4185-4198. https://doi.org/10.1007/s11356-015-4758-2.

Monti, D., 2007. Evaluation de la biocontamination en Chlordecone, $\beta$-Hexachlorocyclohexane et Cadusaphos de Crustacés et Poissons d'eau douce en Guadeloupe. Ministère de l'Ecologie, du Développement et de l'Aménagement durables 1-35.

Multigner, L., Cordier, S., Kadhel, P., Huc-Terki, F., Blanchet, P., Bataille, H., Janky, E., 2007. Pollution par le chlordécone aux Antilles. Quel impact sur la santé de la population? Environnement. Risques et Sante 6, 405-407. https://doi.org/10.1684/ ers.2007.0121.

Multigner, L., Ndong, J.R., Giusti, A., Romana, M., Delacroix-Maillard, H., Cordier, S., Jégou, B., Thome, J.P., Blanchet, P., 2010. Chlordecone exposure and risk of prostate cancer. J. Clin. Oncol. 28, 3457-3462. https://doi.org/10.1200/JCO.2009.27.2153.

Pain, S., Parant, M., 2007. Identification of multixenobiotic defence mechanism (MXR) background activities in the freshwater bivalve Dreissena polymorpha as reference values for its use as biomarker in contaminated ecosystems. Chemosphere 67, 1258-1263. https://doi.org/10.1016/j.chemosphere.2006.11.017.

Patoka, J., Kalous, L., Kopecký, O., 2014. Risk assessment of the crayfish pet trade based on data from the Czech Republic. Biol. Invasions 16, 2489-2494. https://doi.org/ 10.1007/s10530-014-0682-5.

Pedro, S., Fisk, A.T., Tomy, G.T., Ferguson, S.H., Hussey, N.E., Kessel, S.T., McKinney, M. A., 2017. Mercury and persistent organic pollutants in native and invading forage species of the Canadian Arctic: consequences for food web dynamics. Environ. Pollut. 229, 229-240. https://doi.org/10.1016/j.envpol.2017.05.085.

Rotchell, J.M., Ostrander, G.K., 2003. Molecular markers of endocrine disruption in aquatic organisms. J. Toxicol. Environ. Health B Crit. Rev. https://doi.org/10.1080/ 10937400306476.

Schimmel, S.C., Wilson, A.J.J., 1977. Acute Toxicity of Kepone to Four Estuarine Animals, vol. 18. U.S. Environmental Protection Agency Environmental Research Laboratory, pp. 224-227.

Serge, S., 1994. La lutte intégrée contre le charançon noir des bananiers, Cosmopolites sordidus. Fruits 49, 151-162.

Snegaroff, J., 1977. Les résidus d'insecticides organochlorés dans les sols et les rivières de la région bananière de Guadeloupe. Phytiatr. Phytopharm. 26, 251-268.

Sreeram, M., Menon, N., 2005. Histopathological changes in the hepatopancreas of the penaeid shrimp Metapenaeus dobsoni exposed to petroleum hydrocarbons. J. Mar. Biol. Assoc. India.

Tropea, C., Piazza, Y., López, L.S., 2010. Effect of long-term exposure to high temperature on survival, growth and reproductive parameters of the 'redclaw' crayfish Cherax quadricarinatus. Aquaculture 302, 49-56. https://doi.org/10.1016/j. aquaculture.2010.01.027.

Weir, S.M., Salice, C.J., 2012. High tolerance to abiotic stressors and invasion success of the slow growing freshwater snail, Melanoides tuberculatus. Biol. Invasions 14, 385-394. https://doi.org/10.1007/s10530-011-0084-x.

Zeng, H., Ye, H., Li, S., Wang, G., Huang, J., 2010. Hepatopancreas cell cultures from mud crab, Scylla paramamosain. In: Vitro Cellular and Developmental Biology Animal. https://doi.org/10.1007/s11626-009-9259-5. 